\title{
AN OVERVIEW OF PERCEPTIONS AND ATTITUDES TOWARDS EXTENSION SERVICE DELIVERY IN FEZILE DABI DISTRICT, FREE STATE PROVINCE
}

\author{
Sebeho, M. A. ${ }^{1}$ and Stevens, J. B. ${ }^{2}$ \\ Correspondence Author: J. Stevens, Email: joe.stevens@up.ac.za
}

\begin{abstract}
Agricultural extension plays a pivotal role in developing countries and is responsible for promoting and supporting farmers to ensure sustainable agricultural growth and access to key means of production. However, research shows that agricultural extension services have not been performing well, and in most cases is invisible and limited. This research reflects the effectiveness of agricultural extension service delivery as perceived by extension advisors and farmers in the Fezile Dabi District of the Free State Province of South Africa. The findings reflect the perceptions and opinions of 200 smallholder farmers and 15 extension advisors from the Fezile Dabi District in the Free State Province. The majority of farmers perceive extension advisors as a very important source of information and support. Although there are many agricultural development programmes rolled out in the province, only $20 \%$ of the respondents are participating in these programmes because of limited funding and biased behaviour shown towards some elites. Extension advisors in general are of the opinion that they have the necessary competencies and skills to be good agriculturalists. Some of the key recommendations to policy makers are that the funding system for agricultural projects and programmes should be revised and that partnerships between public and private enterprises should be embraced where possible to enhance support to small scale farmers in the district.
\end{abstract}

Keywords: Agricultural extension service, competency, perceptions, smallholder farmers

\section{INTRODUCTION}

Increasing agricultural productivity on small scale agricultural farms in South Africa has often been named as one of the biggest challenges to address food security issues. Agricultural extension has long been seen as a key element for enabling farmers to obtain information and technologies that can improve their livelihoods (Bembridge, 1991). Adupa and Düvel (1999) indicate that the agricultural extension service has not been effective in reaching the smallholder farmers with innovations and technology. This is further confirmed by Düvel (2000), who stated that government extension services in South Africa and other developing countries have performed poorly, especially in relation to addressing the needs of the smallholder farmers. He indicated that the government extension service in South Africa is invisible and extremely limited. The failure to provide adequate extension support initiated the introduction of the Extension Recovery Plan (ERP) in all nine provinces of South Africa during 2008, with the aim of strengthening the capacity of the extension practitioners to be able to better serve farmers. To this end, the ERP aimed at recruiting more staff, and improving the knowledge, skills and professional image of extension officials. Furthermore, Stevens and van

\footnotetext{
${ }^{1}$ M Student in the Department of Agricultural Economics, Extension and Rural Development, University of Pretoria

${ }^{2}$ Department of Agricultural Economics, Extension and Rural Development, University of Pretoria
} 
Heerden (2016) found that current extension initiatives in South Africa are not aligned with the needs of smallholder irrigation farmers. Irrigation farmers are often involved in growing high value crops and therefore require a wide range of extension support covering technical as well as organisational, marketing and entrepreneurial skills (soft skills).

This article seeks to provide an overview of some of the perceptions and opinions of small scale farmers and extension staff from the Fezile Dabi District, Free State Province, regarding the effectiveness of extension service support, and concludes with key findings and policy recommendations.

\section{RESEARCH METHODOLOGY}

In order to assess the opinions and perceptions of extension support, the study was conducted in the Fezile Dabi District of the Free State Province of South Africa. This district is composed of four local municipalities, namely Mafube, Metsimaholo, Moqhaka and Ngwathe (Figure 1).

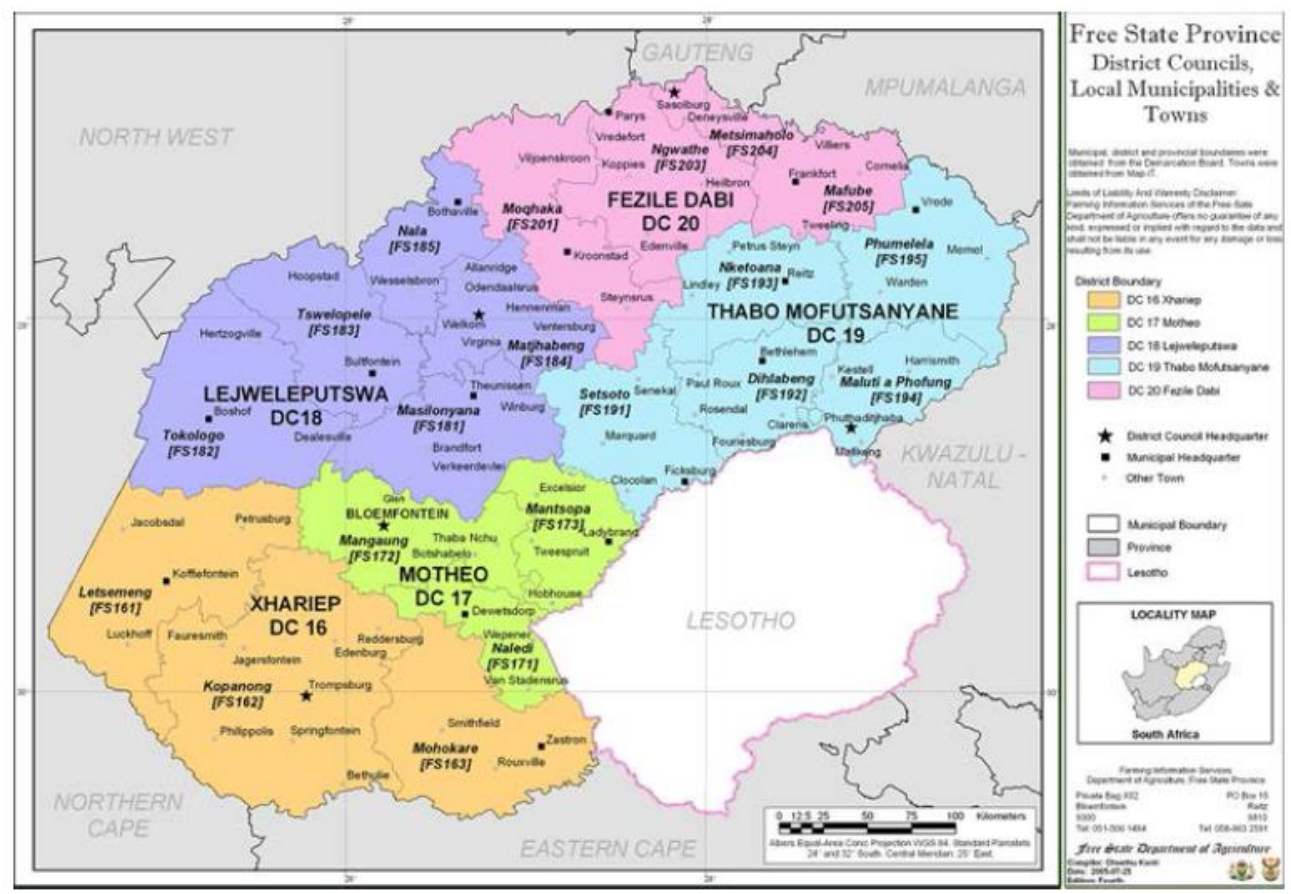

Figure1: Free State Province in terms of local municipalities and district boundaries

The questionnaire survey constituted the main source of data. The sample frame consists of 950 active farmers from 15 towns located in four local municipalities of Fezile Dabi District, who were identified with the help of the respective extension officers from each town or ward. The target sample fraction of 200 farmers was randomly sampled from these 950 farmers. Thus, 50 farmers from each municipality were selected and interviewed.

Furthermore, 15 extension officers serving the 15 towns were interviewed by using a separate structured questionnaire. The purpose of these interviews was to determine whether differential perceptions and opinions between farmers and officials exist regarding the effectiveness of extension service delivery in the district. Descriptive statistical analysis was used in the study to examine the general perceptions and opinions of extension staff and farmers towards 
agricultural extension support. The Statistical Analysis System (SAS), conducted by the University of Pretoria, was used to compute frequencies and descriptive statistics such as means and standard deviations.

\section{RESULTS AND DISCUSSION}

The following results provide opinions and perceptions of farmers and extension staff with regards to agricultural extension service delivery in Fezile Dabi District. The first part of the findings reflects how farmers perceive extension services in their respective wards, while the second part focuses on the views of extension staff with regards to the service delivery.

\subsection{Perceptions and attitudes of farmers towards extension support in the district}

Nagel (2003) defined extension as "organised exchange of information and the purposive transfer of skills". Farm management decisions are underpinned by good information, and therefore farmers require timely and "best fit" or tailored information for effective decision making (Stevens, 2007). Therefore, farmers were asked whom they usually contact for agricultural information and advice.

The responses in Table 1 indicate that $87 \%$ of farmers in the inquiry area prefer contact with their extension advisors. In the Free State Province, extension staff is expected to reflect in their monthly reports not only the number of farmer interventions, but also the type of technical information disseminated to farmers. Farmers also seek advice from other types of information actors, namely fellow farmers (5\%), as well as the private sector, NGO's and cooperatives (8\%) to improve farm management decisions. These elements of privatisation and diversification in the provision of extension are increasingly being witnessed worldwide. Following the adoption literature of Rogers (1983), farmers with different learning requirements would use different information sources, and therefore an important determinant for the adoption of agricultural innovations is how and by whom information is disseminated (Hounkonnou et al., 2012; Stevens \& Letty, 2014).

Table 1: Sources of agricultural information and advice used by farmers $(n=200)$

\begin{tabular}{|l|l|l|l|l|l|l|l|l|l|l|}
\hline & $\begin{array}{l}\text { Extension } \\
\text { officer }\end{array}$ & $\begin{array}{l}\text { Fellow } \\
\text { farmers }\end{array}$ & $\begin{array}{l}\text { Private } \\
\text { companies } \\
\text { fertiliser, } \\
\text { chemical) }\end{array}$ & \multicolumn{2}{l|}{$\begin{array}{l}\text { Cooperative } \\
\text { and NGOs }\end{array}$} & \multicolumn{2}{l|}{ Total } \\
\hline MUNICIPALITIES & $\mathbf{n}$ & $\%$ & $\mathbf{n}$ & $\%$ & $\mathbf{n}$ & $\%$ & n & $\%$ & n & $\%$ \\
\hline NGWATHE & 44 & 88.0 & 4 & 8.0 & 1 & 2.0 & 1 & 2.0 & 50 & 25.0 \\
\hline MOQHAKA & 42 & 84.0 & 1 & 2.0 & 1 & 2.0 & 6 & 12.0 & 50 & 25.0 \\
\hline MAFUBE & 44 & 88.0 & 3 & 6.0 & 0 & 0.0 & 3 & 6.0 & 50 & 25.0 \\
\hline METSIMAHOLO & 44 & 88.0 & 2 & 4.0 & 0 & 0.0 & 4 & 8.0 & 50 & 25.0 \\
\hline TOTAL & $\mathbf{1 7 4}$ & $\mathbf{8 7 . 0}$ & $\mathbf{1 0}$ & $\mathbf{5 . 0}$ & $\mathbf{2}$ & $\mathbf{1 . 0}$ & $\mathbf{1 4}$ & $\mathbf{7 . 0}$ & $\mathbf{2 0 0}$ & $\mathbf{1 0 0}$ \\
\hline
\end{tabular}




\subsection{Frequency of interaction with extension staff}

Continuous interaction builds good relationships between extension and farmers. Riskier or more complex agricultural practices have a higher propensity to be learned from extension, as they are tougher for farmers to adopt (Feder \& Slade, 1984). Farmers were asked to indicate the frequency of interaction with extension and the response is depicted in Table 2.

According to Table 2, $47 \%$ of farmers meet their extension officers once a month, while $10.5 \%$ of farmers indicated they did not have any contact with their extension officer at all. Studies like those of Swanson (2008), show a strong relationship between regular contact with extension systems and the adoption of new agricultural technologies. Therefore, it is often argued that extension should play a more intensive role in supporting of small scale farmers. These findings are worrisome as technical and institutional support is essential for the success of small scale farming projects. Often when government agencies are experiencing financial resource constraints, the first part of the budget to be cut is the operational part. In the interviews with extension staff, limited kilometres allocated for travelling was raised as one of the factors resulting in them not visiting their farmers as regularly as they wanted to. Furthermore, ad-hoc activities like the expectation to transport farmers to departmental events ("indabas") and attending of unscheduled meetings called by their supervisors also have a bearing on the situation. For an extension system to be demand driven, field extension staff need sufficient financial resources and direct control of their extension work plan according to the specific extension programme planned.

Table 2: Frequency of interaction with the extension officer $(n=200)$

\begin{tabular}{|l|l|l|l|l|l|l|l|l|l|l|l|l|l|}
\hline & $\begin{array}{l}\text { Once a } \\
\text { week }\end{array}$ & $\begin{array}{l}\text { Once in } \\
\text { two } \\
\text { weeks }\end{array}$ & \multicolumn{2}{l|}{$\begin{array}{l}\text { Once in } \\
\text { a month }\end{array}$} & \multicolumn{2}{l|}{ Never } & \multicolumn{2}{l|}{ Other } & \multicolumn{2}{l|}{ Total } \\
\hline MUNICIPALITIES & $\mathbf{n}$ & $\%$ & $\mathbf{n}$ & $\%$ & $\mathbf{n}$ & $\%$ & $\mathbf{n}$ & $\%$ & $\mathbf{n}$ & $\%$ & $\mathbf{n}$ & $\%$ \\
\hline NGWATHE & 1 & 2.0 & 5 & 10.0 & 33 & 66.0 & 10 & 20.0 & 1 & 2.0 & 50 & 25.0 \\
\hline MOQHAKA & 11 & 22.0 & 13 & 26.0 & 21 & 42.0 & 2 & 4.0 & 3 & 6.0 & 50 & 25.0 \\
\hline MAFUBE & 27 & 54.0 & 10 & 20.0 & 9 & 18.0 & 3 & 6.0 & 1 & 2.0 & 50 & 25.0 \\
\hline METSIMAHOLO & 1 & 2.0 & 8 & 16.0 & 30 & 60.0 & 6 & 12.0 & 5 & 10.0 & 50 & 25.0 \\
\hline TOTAL & $\mathbf{4 0}$ & $\mathbf{2 0 . 0}$ & $\mathbf{3 6}$ & $\mathbf{1 8 . 0}$ & $\mathbf{9 3}$ & $\mathbf{4 6 . 5}$ & $\mathbf{2 1}$ & $\mathbf{1 0 . 5}$ & $\mathbf{1 0}$ & $\mathbf{5 . 0}$ & $\mathbf{2 0 0}$ & $\mathbf{1 0 0}$ \\
\hline
\end{tabular}

\subsection{Preferred extension methods for service delivery and participation in extension programmes}

The ideal outcome of extension services is that different client groups in different contexts are satisfied with their access to services. Different extension methods and approaches are used in the Free State Province as a suite of complementary capacity building avenues. Farmers were asked to reveal their preferred extension method for service delivery. The majority of farmers $(70 \%)$ in the various wards in Fezile Dabi prefer regular group contact for agricultural development, while $28 \%$ of farmers prefer individual farm visits. A possible reason for this opinion could be that a precondition for farmers to participate in departmental projects and programmes offered is to be well organised into structured groups. According to Stevens and Terblanche (2004), the establishment of effective farmer groups is a prerequisite for successful 
agricultural development, although one-on-one extension activities are also critical in bringing about management and technological change. Although there is no single extension approach suited to all situations in South Africa, approaches and methods must be adapted to local situations and conform to the principles of extension delivery (Stevens, 2008).

Various official agricultural development programmes are employed in the district, namely the Comprehensive Agricultural Support Programme (CASP), ILIMA/Letsema, Mechanisation, Re Kgaba ka Diratswana, Massification (crops and livestock), and Land Care. These programmes and service providers of support to development beneficiaries all act as intermediaries in the agricultural value chain. Agricultural projects implemented in the district include the construction of vegetable tunnels, poultry houses and purchasing of production inputs. Table 3, however, indicates that $80.3 \%$ of farmers are not engaged in any of the above mentioned extension or development projects and programmes. The key question based on this finding is whether or not farmers have been consulted sufficiently on the type of support they truly need from government or whether these programmes are only earmarked for specific people. Active farmer participation in agricultural programmes depends on the utility the farmer expects to derive from participation.

The overall impression created by the responses depicted in Table 3 is that a very small percentage of small scale farmers in the district actively participate in any of the mentioned financial support programmes. A possible reason for the relatively low percentage of farmers involved in agricultural development programmes and projects could be due to the limited funding available through the Comprehensive Agricultural Support Programme (CASP) and ILIMA/LETSEMA, and the possible biased behaviour towards some elite that are selected for participation.

Table 3: Farmer engagement in extension programmes or projects $(n=197)$

\begin{tabular}{|l|l|l|l|l|l|l|}
\hline & \multicolumn{2}{|c|}{ Yes } & \multicolumn{2}{c|}{ No } & \multicolumn{2}{c|}{ Total } \\
\hline MUNICIPALITIES & n & \% & n & \% & n & \% \\
\hline NGWATHE & 9 & 18.0 & 41 & 82.0 & 50 & 25.4 \\
\hline MOQHAKA & 5 & 10.4 & 43 & 89.6 & 48 & 24.3 \\
\hline MAFUBE & 9 & 18.4 & 40 & 81.6 & 49 & 24.9 \\
\hline METSIMAHOLO & 16 & 32.0 & 34 & 68.0 & 50 & 25.4 \\
\hline TOTAL & $\mathbf{3 9}$ & $\mathbf{1 9 . 7}$ & $\mathbf{1 5 8}$ & $\mathbf{8 0 . 3}$ & $\mathbf{1 9 7}$ & $\mathbf{1 0 0}$ \\
\hline
\end{tabular}

CASP was launched in 2004, and while not the largest form of agricultural support, it quickly became the most significant capital budget line potentially available to small scale farmers. Despite a growing budget (almost double) over the last couple of years, CASP continued to benefit more or less the same number of people, obvious at the expense of reaching larger number of farmers in the district.

\subsection{Perceived competency of extension officers}

The role of extension as an actor in the value chain has changed over the years from a sole provider of information to a facilitator and/or broker of information from different sources (Stevens \& van Heerden, 2016). Farmers look upon extension officers as advisors who provide information and advice that will enable them to make informed farming decisions. The main 
need for successful extension intervention according to Stevens, van Heerden, Buys and Laker (2012) is sound technical knowledge, which has to be credible and unbiased to win acceptance by agricultural producers. In responding to a question on whether their extension officers are technically competent, $94.5 \%$ of the farmers are of the opinion that they are competent to some extent in performing their extension duties (Table 4).

Table 4: Perceived technical competency of extension officers by farmers $(n=200)$

\begin{tabular}{|l|l|l|l|l|l|l|l|l|l|l|}
\hline & $\begin{array}{l}\text { Very } \\
\text { incompetent }\end{array}$ & \multicolumn{3}{l|}{ Incompetent } & \multicolumn{2}{l|}{ Competent } & \multicolumn{2}{l|}{$\begin{array}{l}\text { Highly } \\
\text { competent }\end{array}$} & \multicolumn{2}{l|}{ Total } \\
\hline MUNICIPALITIES & $\mathbf{n}$ & $\mathbf{\%}$ & $\mathbf{n}$ & $\mathbf{\%}$ & $\mathbf{n}$ & $\boldsymbol{\%}$ & $\mathbf{n}$ & $\%$ & $\mathbf{n}$ & $\%$ \\
\hline NGWATHE & 2 & 4.0 & 5 & 10.0 & 35 & 70.0 & 8 & 16.0 & 50 & 25.0 \\
\hline MOQHAKA & 0 & 0.0 & 0 & 0.0 & 22 & 44.0 & 28 & 56.0 & 50 & 25.0 \\
\hline MAFUBE & 1 & 2.0 & 3 & 6.0 & 18 & 36.0 & 28 & 56.0 & 50 & 25.0 \\
\hline METSIMAHOLO & 0 & 0.0 & 0 & 0.0 & 32 & 64.0 & 18 & 36.0 & 50 & 25.0 \\
\hline TOTAL & $\mathbf{3}$ & $\mathbf{1 . 5}$ & $\mathbf{8}$ & $\mathbf{4 . 0}$ & $\mathbf{1 0 7}$ & $\mathbf{5 3 . 5}$ & $\mathbf{8 2}$ & $\mathbf{4 1 . 0}$ & $\mathbf{2 0 0}$ & $\mathbf{1 0 0}$ \\
\hline
\end{tabular}

Farmers expect from their extension officers a defined body of technical knowledge and skills, as well as a variety of social and interpersonal skills for professional extension service delivery (Stevens, 2008).

\subsection{Perceived credibility and trustworthiness of extension officers}

For extension to be effective as part of the innovation system, they need to be professionally competent, respected, trusted, have a sense of responsibility, and be accepted by their clientele, regardless of education or group affiliation. To that end, advice needs to be objective, unbiased and useful (Stevens, 2008). Table 5 illustrates that $92.5 \%$ of farmers found their extension officers to be trustworthy (ethical and reliable in dealing with farmers) and credible. Training is critical for the development of skills and competencies of extension staff, which are necessary for building of their credibility amongst the farmer community.

Table 5: Frequency distribution of extension officer's trustworthiness and credibility ( $n=200$ )

\begin{tabular}{|c|c|c|c|c|c|c|c|c|c|c|}
\hline & \multicolumn{2}{|c|}{ Very low } & \multicolumn{2}{|c|}{ Low } & \multicolumn{2}{|c|}{ High } & \multicolumn{2}{|c|}{ Very high } & \multicolumn{2}{|c|}{ Total } \\
\hline MUNICIPALITIES & $\mathbf{n}$ & $\%$ & $\mathbf{n}$ & $\%$ & $\mathbf{n}$ & $\%$ & $\mathbf{n}$ & $\%$ & $\mathbf{n}$ & $\%$ \\
\hline GWATHE & 3 & 6.0 & 7 & 14.0 & 35 & 70.0 & 5 & 10.0 & 50 & 25.0 \\
\hline MOQHAKA & 1 & 2.0 & 2 & 4.0 & 16 & 32.0 & 31 & 62.0 & 50 & 25.0 \\
\hline MAFUBE & 1 & 2.0 & 1 & 2.0 & 19 & 38.0 & 29 & 58.0 & 50 & 25.0 \\
\hline METSIMAHOLO & 0 & 0.0 & 0 & 0.0 & 34 & 68.0 & 16 & 32.0 & 50 & 25.0 \\
\hline TOTAL & 5 & 2.5 & 10 & 5.0 & 104 & 52.0 & 81 & 40.5 & 200 & 100 \\
\hline
\end{tabular}




\subsection{Perceived professional status of extension officers}

The extension systems in South Africa have become pluralistic in nature, with support services provided not only by government, but also NGOs and private organisations. In some communities, the extension agent may serve as a community organiser, while in others they can act as "connectors", connecting people with knowledgeable people with the leverage to get things done (Stevens \& van Heerden, 2016). However, for an extension advisor to be effective, the importance of motivation, commitment, skills necessary to provide practical and useful advice to farmers and to explore alternatives cannot be overemphasised. Without these professional skills and competence, extension advisors would not be equipped to take up their role for dialoguing successfully with farmers.

Table 6 shows that all farmers from the various municipalities perceived their extension advisors to have a relatively higher professional status than other agricultural role players in the district. The exception was Metsimaholo and Ngwathe, where the status of extension officers was perceived to be much lower. Possible reasons for the opinions of Metsimaholo and Ngwathe farmers are that extension officers are sharing government vehicles in these wards and are therefore sometimes unable to attend to urgent requests from farmers. In addition, offices are poorly equipped with basic office equipment such as fax machines and telephones that do not work, as well as limited travelling budget allocations.

Table 6: Perceived status of extension workers in comparison to other professionals in the area $(n=200)$

\begin{tabular}{|l|l|l|l|l|l|l|l|l|l|l|}
\hline MUNICIPALITIES & Very low & \multicolumn{2}{|c|}{ Low } & \multicolumn{2}{c|}{ High } & \multicolumn{2}{c|}{ Very high } & \multicolumn{2}{c|}{ Total } \\
\hline & n & $\%$ & n & $\%$ & n & $\%$ & n & $\%$ & n & $\%$ \\
\hline NGWATHE & 2 & 4.0 & 35 & 70.0 & 12 & 24.0 & 1 & 2.0 & 50 & 25.0 \\
\hline MOQHAKA & 6 & 12.0 & 14 & 28.0 & 18 & 36.0 & 12 & 24.0 & 50 & 25.0 \\
\hline MAFUBE & 1 & 2.0 & 8 & 16.0 & 24 & 48.0 & 17 & 34.0 & 50 & 25.0 \\
\hline METSIMAHOLO & 0 & 0.0 & 33 & 66.0 & 17 & 34.0 & 0 & 0.0 & 50 & 25.0 \\
\hline TOTAL & $\mathbf{9}$ & $\mathbf{4 . 5}$ & $\mathbf{9 0}$ & $\mathbf{4 5 . 0}$ & $\mathbf{7 1}$ & $\mathbf{3 5 . 5}$ & $\mathbf{3 0}$ & $\mathbf{1 5 . 0}$ & $\mathbf{2 0 0}$ & $\mathbf{1 0 0}$ \\
\hline
\end{tabular}
3.7 Extension advisors' opinions and perceptions regarding their own professional skills,
approaches and legitimacy

The following findings reflect the opinions of the 15 extension advisors interviewed in the district. A BTech degree was obtained by $47 \%$ of the extension advisors in the district, while $26.9 \%$ obtained either a BSc or post graduate qualification in Sustainable Resource. The remainder of the staff, especially those older than 40 years, have an Agricultural Diploma. Furthermore, $13 \%$ of the extension advisors obtained formal extension training through a certificate or diploma course, while the remainder have majored in crop and livestock, which is appropriate for an area like Fezile Dabi where mainly mixed farming systems are practised. 


\subsubsection{Extension competencies}

Extension officers agree that the most essential skill required to do their job is technical knowledge of agriculture. The majority of extension officers $(86 \%)$ are of the opinion that they have the necessary technical skills to be a good agriculturalist, while $80 \%$ are confident they have the range of extension (or other social) capabilities and attributes needed to do their job well. The perception of extension staff with regards to their technical and extension competencies has been measured on a five-point Likert scale. This positiveness was also reflected in their opinion of qualities and abilities required to do their work properly and effectively. It was therefore no surprise that $53.3 \%$ of extension advisors are satisfied with outcomes of extension support in their respective wards.

\subsubsection{Farmers' attitudes towards extension}

A fair amount of extension officers (40\%) are of the opinion that farmers are not always positive towards the support they receive from extension service, since many farmers expect more of extension than providing training to farmers and helping them with decision making. They primarily expect extension to assist them with accessing financial funding and loans. Although extension is expected to support farmers with the preparation of business plans and applications for credit and financial support within financial aid programmes offered by the Department of Agriculture and Rural Development (like CASP, ILIMA and Land Care funds), extension advisors do not have the final say in this regard. When extension advisors cannot provide this type of support for farmers or projects, farmers' attitudes towards extension tend to change negatively. Farmers are more likely to engage with support staff who they perceive to be relevant to their needs and where they can benefit financially.

\subsubsection{Extension approach currently used}

There are many extension approaches used to promote agricultural development. Traditionally, there has been one major paradigm promoted to enhance agricultural development, namely "technology supply push". The technology supply push involves the transfer of information and technologies via a top down approach using a central source of information mode, without taking the needs of farmers into account. A different paradigm of agricultural development takes into account the way information is shared and sourced. The participatory approach is one of these approaches recommended in the Department of Agriculture's Norms and Standards document (Department of Agriculture, 2005). Furthermore, it is believed that there is growing evidence that when rural people organise for their own benefit, much more can be achieved. Participatory approaches are very effective where innovations have large knowledge components or are regionally specific.

The Free State Department of Agriculture and Rural Development currently promote the commodity approach, where the extension intervention focuses on the production of a specific commodity like beef, poultry, grain crops or vegetables. Table 7 indicates that $46.7 \%$ of extension officers use the participatory approach in their support of farmers, while $40 \%$ of extension officers are using the project approach. The project approach is very popular, especially in Moqhaka (67\%) and Metsimaholo (67\%), where the Department of Agriculture and Rural Development promotes this approach for the implementation of CASP, ILIMA and Land Care support programmes. Both the participatory and project approaches are also used to serve the needs of specific commodity producers. 
Table 7: Extension approaches currently used in the extension wards in Fezile Dabi District (n=15)

\begin{tabular}{|l|l|l|l|l|l|l|l|l|l|l|l|}
\hline \multicolumn{10}{|c|}{ MUNICIPALITIES } \\
\hline & Ngwathe & \multicolumn{2}{|l|}{ Moqhaka } & Mafube & \multicolumn{2}{|l|}{ Metsimaholo } & \multicolumn{2}{|l|}{ Total } \\
\hline $\begin{array}{l}\text { Participatory } \\
\text { approach }\end{array}$ & 4 & 80.0 & 1 & 33.3 & 2 & 50.0 & 0 & 0.0 & 7 & 46.7 \\
\hline $\begin{array}{l}\text { Project } \\
\text { approach }\end{array}$ & 1 & 20.0 & 2 & 66.7 & 1 & 25.0 & 2 & 66.7 & 6 & 40.0 \\
\hline $\begin{array}{l}\text { Training and } \\
\text { visit approach }\end{array}$ & 0 & 0.0 & 0 & 0.0 & 1 & 25.0 & 1 & 33.3 & 2 & 13.3 \\
\hline TOTAL & $\mathbf{5}$ & $\mathbf{3 3 . 3}$ & $\mathbf{3}$ & $\mathbf{2 0 . 0}$ & $\mathbf{4}$ & $\mathbf{2 6 . 7}$ & $\mathbf{3}$ & $\mathbf{2 0 . 0}$ & $\mathbf{1 5}$ & $\mathbf{1 0 0}$ \\
\hline
\end{tabular}

\subsubsection{Perceived legitimacy of extension advisors}

To be effective, extension staff needs to build their legitimacy by fostering high levels of trust and credibility in their local communities. To maintain this trust and credibility, their advice needs to be objective and useful. There are numerous components for establishing an agent's legitimacy, namely cited technical knowledge, interacting with credible and trusted local partners, motivation and vision (Kahan, 2013). The majority of extension advisors (80\%) are of the opinion that they experience a relatively high professional status and legitimacy in the farmer community in comparison to the wide range of actors from other sectors like NGOs and the private sector. Some of them even expressed their intention to motivate their children to become extension officers one day. Many of the extension advisors also indicated that they are active in organising campaigns at schools where they provide learners with background information about different careers to follow in agriculture and try to create a better understanding of the concept "agriculture".

\subsubsection{Critical issues to be addressed}

Extension officers were asked to indicate the critical issues that need to be addressed for improving extension support:

- Funding system of newly or existing projects to farmers should be improved and revised where applicable.

- Extension should be geared to improve establishing of proper linkages with formal markets.

- Communication between stakeholders in existing projects should be better coordinated to prevent the current "silo approach" followed.

- Lack of the critical resources and operational funding like vehicles and budgets for cell phones should be addressed to enable extension to service farmers effectively.

- Farmers require proper training and support regarding farmer group functioning, especially within a project and how to deal with conflict when it occurs.

- Empowerment of extension staff with regards to technical skills and competencies (especially crop and livestock). 


\section{CONCLUSIONS AND RECOMMENDATIONS}

Currently, the extension footprint in Fezile Dabi District is mainly focused on small scale commercial farmers. Given the character of agriculture in the district, the question that arises from the study is what should the key objectives and focus of government extension be. Should extension primarily focus on the commercial small scale for the market or should it also focus on the subsistence smallholders in a bid to reduce poverty and improve livelihoods through food gardening activities?

The following policy implications and recommendations are made based on the results of the study conducted in an effort to improve effectiveness of agricultural services in Fezile Dabi District.

\section{a. Interaction between extension and farmers}

Findings suggest that although farmers had access to extension, the number of visits and interaction between extension and farmers were not satisfactory, and farmers were displeased with the number of meetings held with regards to their activities and follow up meetings after a farmer group was established. A reality is that smallholder farmers are miles away when compared to commercial farmers and to bridge the gap requires a serious review of the current extension policy and funding of extension in the district.

\section{b. Range of value chain actors}

The study identified that a wide range of actors are involved in supporting farmers in the district. It is important to pay attention to the roles that each one is playing in chain governance and functioning. Public extension should be prepared and willing to take up the role of brokering and facilitating support from government and other agencies in the district. Partnerships between public and private enterprises should be established and maintained to enhance support to small scale farmers in the district. For small scale and emerging farmers, public-private partnerships are useful for the provision of production inputs, as well as markets for their agricultural products.

\section{c. Farming systems research and extension}

Farmers are not just the recipients of the information and technology, but the linkages between the extension advisor, farmers and research, which should be strengthened. Applied research is required for effective functioning of extension officers and the farmers. Farmers indicated that they would like to see improved involvement in the planning of their farm activities together with extension and research. The creation of on-farm trials and demonstration plots are recommended as one of the approaches to be used for the adoption of new technology or innovations. Results showed that there is a lack of adaptive research to develop innovations and farming systems which are acceptable and profitable to the farmers.

\section{d. Financial support}

Inadequate or no funding is a challenge for the promotion of sustainable agriculture as perceived by both the farmers and the extension officers. The current allocation of funding by the department to projects should be reviewed, taking into consideration the small number of 
respondent farmers participating and benefitting from government aid support programmes like ILIMA and CASP. The top down approach followed in identification of stakeholders and funding of agricultural projects on different enterprises is insufficient in addressing the needs of all farmers in the district. Extension should also play a more prominent role in identifying stakeholders to participate in these development aid programmes and projects.

e. Training of farmers and extension officers

Although farmers and extension staff are happy with the technical and general competency levels of extension advisors in the area, agriculture is dynamic in nature and ever changing, which requires both farmers and extension staff to be regularly trained to keep abreast of changes in the sector. Regular in-service training of extension staff on both technical and soft skills is required to perform their work effectively and efficiently. Adequate allocation of departmental budgets for this training is required, even after the Extension Recovery Plan comes to a halt.

\section{REFERENCES}

ADUPA, J.D.G.H. \& DÜVEL, G.H., 1999. The importance of opinion leaders in agricultural production among male and female farmers of Kasenge Parish in the Mukonono district of Uganda. S. Afr. J. Agric. Ext., 28(1):32-44.

BEMBRIDGE, T.J., 1991. Practical guidelines for agricultural extension workers: A Field Manual. Development Bank of Southern Africa.

DEPARTMENT OF AGRICULTURE, 2005. Norms and Standards for extension and advisory services in Agriculture.

DÜVEL, G.H., 2000. Towards an appropriate extension approach for agricultural and rural development in South Africa. S. Afr. J. Agric. Ext., 29(1):10-23.

FEDER, G. \& SLADE, R., 1984. The acquisition of information and the adoption of new technology. Am. J. Agric. Econ., 66(3):312-320.

HOUNKONNOU, D., KOSSOU, D., KUYPER, T.W., LEEUWIS, C., NEDERLOF, E.S., RÖLING, N., SAKYI-DAWSON, O., TRAORÉ, M. \& VAN HUIS, A., 2012. An innovation systems approach to institutional change: Smallholder development in West Africa. Agric. Sys., 108:74-83.

KAHAN, D., 2013. The role of the farm management specialist in extension. Rome: Food and Agricultural Organization of the United Nations.

NAGEL, U.J., 2003. Back on the agenda: Extension and its institutional linkages - some personal observations on the rediscovery of a key player. Tropentag in Goettingen, Germany.

ROGERS, E.M., 1983. Diffusion of innovations. Simon and Schuster.

STEVENS, J.B., 2007. Professional extension support: a prerequisite for sustainable development. S. Afr. J. Agric. Ext., 36(1):170-189. 
S. Afr. J. Agric. Ext.

Vol. 47 No. 1, 2019: 61 - 72

http://dx.doi.org/10.17159/2413-3221/2019/v47n1a490
Sebeho \& Stevens

(License: CC BY 4.0)

STEVENS, J.B., 2008. Study guide. Extension approaches and principles. University of Pretoria, Pretoria.

STEVENS, J.B. \& LETTY, B., 2014. Understanding the dynamics of multi-stakeholder innovation systems and the opportunities for joint learning by small scale farmers. $S$. Afr. J. Agric. Ext., 42(2):24-38.

STEVENS, J.B. \& TERBLANCHE, S.E., 2004. Sustainable agricultural development through effective farmer group. S. Afr. J. Agric. Ext., 33(1):40-51.

STEVENS, J.B., VAN HEERDEN, P.S., BUYS, F. \& LAKER, M.C., 2012. Training material for extension advisors in irrigation management. Report No. TT, 539, 12.

STEVENS, J.B. \& VAN HEERDEN, P.S., 2016. Knowledge brokering and dissemination of irrigation management guidelines for training of extension advisors. Report No. KV, $356,16$.

SWANSON, B.E., 2008. Global review of good agricultural extension and advisory service practices. Rome: Food and Agricultural Organization of the United Nations. 